\title{
Quality of life of patients with vasculogenic ulcers in outpatient treatment*
}

\author{
Qualidade de vida de pacientes com úlceras vasculogênicas em tratamento ambulatorial
}

Brenda Kelly da Silva Monte ${ }^{1}$, Elaine Cristina Carvalho Moura ${ }^{1}$, Jéssica Pereira Costa ${ }^{1}$, Grazielle Roberta Freitas da Silva ${ }^{1}$, Vanessa Caminha Aguiar Lopes ${ }^{1}$

Objective: assess the quality of life of patients with vasculogenic ulcers in outpatient treatment. Methods: this is a quantitative, descriptive-comparative study of the type before and after, carried out at an outpatient unit specialized in the treatment of complex wounds, with patients suffering from vasculogenic ulcers, totaling 10 patients and 26 wounds. Results: the overall score for quality of life increased 6.8 units on average. In the overall evaluation, epithelialized tissue, presence of foul odor, conduction of surgical debridement and use of hydrogel were influencers of higher scores. Conclusion: there was a significant increase in quality of life scores in all areas and in the overall score. The aspects type of tissue and odor influenced significantly the increase of the scores of all the domains and of the overall score.

Descriptors: Quality of Life; Leg Ulcer; Ambulatory Care.

Objetivo: avaliar a qualidade de vida de pacientes acometidos por úlceras vasculogênicas em tratamento ambulatorial. Métodos: estudo quantitativo, descritivo-comparativo, do tipo antes e depois, realizado em ambulatório especializado no tratamento de feridas complexas, com pacientes acometidos por úlceras vasculogênicas, totalizando 10 pacientes e 26 feridas. Resultados: o escore global de qualidade de vida aumentou 6,8 unidades na mediana. Na avaliação global, tecido epitelizado, presença de odor fétido, realização de desbridamento cirúrgico e uso de hidrogel foram influenciadores do aumento dos escores. Conclusão: observou-se aumento significativo dos escores de qualidade de vida em todos os domínios e no escore global. Os aspectos tipo de tecido e odor influenciaram significativamente o aumento dos escores de todos os domínios e do escore global.

Descritores: Qualidade de Vida; Úlcera da Perna; Assistência Ambulatorial.

\footnotetext{
*Extracted from the Undergraduate Work "Avaliação da qualidade de vida de pacientes com úlceras vasculogênicas atendidos em âmbito ambulatorial”, Universidade Federal do Piauí, 2016.

${ }^{1}$ Universidade Federal do Piauí. Teresina, PI, Brazil. 


\section{Introduction}

In Brazil, there is a high number of cases of chronic wounds. The consequences of this problem have worried health professionals, especially nurses, concerning patients' biopsychosocial aspects. The significant prevalence and incidence of chronic wounds have repercussions on the financial, social and emotional areas of the individuals affected, which leads to consequences such as amputation of limbs, absence from work, restrictions that affect personal skills and self-esteem, which may even lead to death ${ }^{(1)}$.

These injuries can be decisive for lifestyle changes, since they involve feelings of worry, frustration, hopelessness related to health and to the possibility of reversal of the case, as well as for failing to display quick responses to the treatment before relapses. In addition, factors such as overload and exhaustion are developed by patients and caregivers and can result in psychological damage, such as low self-esteem, feelings of inferiority and depression ${ }^{(2)}$.

In this sense, one has developed studies that offer measurement tools capable of evaluating the quality of health care to restore the quality of life of people with wounds, upon extensive and reliable assessment of the health concerns of the population, such as Ferrans \& Powers Quality of life Index - Wound Version (FPQLI-WV) ${ }^{(3)}$.

When considering the impact on the quality of life caused by vasculogenic injuries, health professionals should be alert to guide patients regarding the treatment of the underlying disease, self-care, and encourage the pursuit of living ordinary activities as much as possible. Attention must also be provided to prevent lesions in patients with vascular diseases, as well as to the recurrence of lesions and to their treatment appropriately ${ }^{(4)}$. Due to these factors, it is appropriate to conduct this study.

Thus, the purpose of this study was to evaluate the quality of life of patients with vasculogenic ulcers in outpatient treatment.

\section{Methods}

This is a descriptive-comparative study, conducted at an outpatient unit specialized in the treatment of complex wounds, which is formed by a team of nurses and nursing technicians, located in northeastern Brazil, whose data was collected between July and December 2016. The study population comprised patients with vasculogenic ulcers admitted to the wound outpatient unit.

The sampling was non-probabilistic for convenience. The sample consisted of 10 patients and a total of 26 wounds that met the following inclusion criteria: age equal or more than 18 years old; having at least one chronic wound of the vasculogenic ulcer type; and being admitted to outpatient treatment in the period of data collection. Those affected from acute wounds and who did not perform exclusive treatment in the wounds outpatient unit were excluded.

Patients were approached during admission in the clinic and had their sociodemographic and clinical information filled, using standardized printed material from the unit, followed by two applications of FPQLI-WV. The first assessment was carried out before the wound treatment in the clinic; and the second after at least four bandage changes during treatment. The bandage changing time was determined according to the evaluation.

The instrument of wound notification in the primary care service contained patients' sociodemographic characteristics (age, sex, marital status, date of birth, family income and education) and their clinical data, such as risk factors associated (diabetes mellitus, systemic high blood pressure, etc.), drugs in use and mobility. The printed material also offers data of evaluation of the wounds, such as etiology, quantity, time of existence, location, size, type of tissue, amount of exudate, appearance, odor, if there was previous debridement, edges, if there was edema and measurement of ache. It also incorporates a survey about the prior treatment of wounds, questioning who made the 
bandage, changing frequency, treatment used, specification and quantity of material used and drawing to indicate the location of the lesion. The FPQLI-WV underwent cross-cultural validation for Brazilian Portuguese and consists of 34 items, divided into four areas: Health and Functioning, Socioeconomic, Psychological/Spiritual and Family ${ }^{(3)}$.

The data were processed using the software Statistical Package for the Social Sciences, version 21.0, and descriptive statistics were calculated such as mean, median, standard deviation, interquartile range, minimum and maximum for quantitative variables; and frequencies for the qualitative ones. The significance level for inferential analysis was set at $5 \%$. The Wilcoxon test was used to compare the scores of the first and second evaluation of patients. The Mann-Whitney and Kruskal-Wallis test were used to compare the variation in scores between the distribution characteristics of the wounds. It was also performed the Spearman correlation test for quantitative variables and variation of domain scores and overall score.

The study complied with the formal requirements contained in the national regulatory and international standards for research involving human beings.

\section{Results}

The average age of patients with vasculogenic ulcers was $64.8( \pm 15.5)$ years old, with a minimum of 41.0 and maximum of 87.8 years of age, distributed equally between the sexes. Most of them, 7 (70.0\%) were married or in a stable relationship, a big part, 8 (80.0\%) came from the capital of Piauí, Brazil, with average monthly individual income of $\mathrm{R} \$ 950.00$, ranging from $R \$ 700.00$ to $R \$ 1,760.00$ and average monthly family income of $R \$ 1,352.00$, with a minimum of $\mathrm{R} \$ 700.00$ and a maximum of $\mathrm{R} \$ 3,000.00$.

Most patients were sent by primary care units, $7(70.0 \%), 2$ went there by themselves $(20.0 \%)$ and 1 $(10.0 \%)$ was sent by an urgent hospital. There were nine $(90.0 \%)$ who presented any kind of risk factors, systemic hypertension in five $(50.0 \%)$; diabetes in four (40.0\%); and three (30.0\%) were insulin dependent. Other data for evaluation of injuries are listed in Table 1.

Table 1 - Characteristics of vasculogenic ulcers, according to the quantity of ulcers $(n=26)$ of participants

\begin{tabular}{|c|c|}
\hline Characteristics & n (\%) \\
\hline \multicolumn{2}{|l|}{ Anatomical location } \\
\hline Right leg & $6(23.1)$ \\
\hline Left leg & $4(15.4)$ \\
\hline Right malleolus & $3(11.5)$ \\
\hline Left malleolus & $2(7.7)$ \\
\hline Foot & $11(42.3)$ \\
\hline \multicolumn{2}{|l|}{ Position of the lesion } \\
\hline Medial & $8(30.8)$ \\
\hline Side & $9(34.6)$ \\
\hline Previous & $3(11.5)$ \\
\hline Rear & $5(19.2)$ \\
\hline Combination & $1(3.8)$ \\
\hline \multicolumn{2}{|l|}{ Kind of tissue } \\
\hline Epithelialization & $5(19.2)$ \\
\hline Granulation & 7 (26.9) \\
\hline Devitalized & $12(46.2)$ \\
\hline Necrotic & $2(7.7)$ \\
\hline \multicolumn{2}{|l|}{ Amount of exudate } \\
\hline Scarce & $3(11.5)$ \\
\hline Moderate & $21(80.8)$ \\
\hline Abundant & $2(7.7)$ \\
\hline \multicolumn{2}{|l|}{ Aspect of exudate } \\
\hline Serous & $21(80.8)$ \\
\hline Serosanguineous & $5(19.2)$ \\
\hline \multicolumn{2}{|l|}{ Foul odor } \\
\hline Present & $5(19.2)$ \\
\hline Absent & $21(80.8)$ \\
\hline \multicolumn{2}{|l|}{ Wound edges* } \\
\hline hydrated & $20(76.4)$ \\
\hline Dryness / desquamation & $4(14.3)$ \\
\hline Erythema & $4(14.3)$ \\
\hline \multicolumn{2}{|l|}{ Edema } \\
\hline Present & $13(50.0)$ \\
\hline Absent & $13(50.0)$ \\
\hline
\end{tabular}


Patients had an average of 2.6 wounds $( \pm 1.4)$ with up to five, so that $24(92.3 \%)$ were venous and two $(7.7 \%)$ were arterial. The time of existence of the wounds ranged from one month to 10 years, with an average of $40.1( \pm 32.9)$ months. The wounds were on average $5.4( \pm 2.8) \mathrm{cm}$ long (minimum of 1 and maximum of $10 \mathrm{~cm}), 4.6( \pm 3.4) \mathrm{cm}$ (minimum 1 , maximum $15 \mathrm{~cm}$ ) and $0.3( \pm 0.3)$ deep $(\min 0$, max 2 $\mathrm{cm})$. The average area was $19.9( \pm 31.3)$ ranging from 0.5 to $12 \mathrm{~cm}^{2}$.

All the patients reported having maximum pain (level 10) for all the vasculogenic ulcers. The bandages were performed only by nurses. The rate of exchange was mainly whenever necessary in 11 participants $(42.3 \%)$ or once a week in $10(38.5 \%)$.

The treatment was accomplished primarily with zinc oxide in eight subjects (30.8\%); followed by hydrogel (19.2\%); and Unna boot in four (15.4\%). The skin and lesion cleansing was performed with povidone-iodine (84.6\%) and chlorhexidine in topical use (23.1\%). There were seven wounds (26.9\%) that presented dermatitis or eczema, and as to the compression, most of them were inelastic 22 (84.6\%).
Table 2 shows the measurements of quality of life in both patients evaluations.

The domain that had the lowest median score in the first evaluation was Health and Functioning 16.0 ( $\mathrm{SD}=5.9$ ), showing bigger increase in the second evaluation, with increase of 11.4 units in the median, keeping in this last one with a smaller value if compared with the other domains 27.4, being significant $(\mathrm{p}=0.005)(\mathrm{SD}=3.0)$. The domain Family was the one that presented the smallest median variation, at 4.8 units, however, with significance $(\mathrm{p}=0.028)$. The standard deviation in this domain was 6.9 in the first assessment and 2.8 in the second (Table 2).

The increases in the median of the socio-economic domains were significant $(\mathrm{p}=0.012)$, in 5.2 units (SD in the first evaluation: 5.9; in the second evaluation: 2.6) and Psychological/Spiritual ( $\mathrm{p}=0.037)$, in 4.9 units (SD in the first assessment: 5.1 ; in the second evaluation: 2.6). The overall score for quality of life had an increase of 6.8 units in the median, with an increase of 12.6 units in the minimum amount and of 2.1 units in the maximum value, presenting thus significance (Table 2).

Table 2 - Quality of life measures for dimensions and global score of quality of life in the evaluation of patients with vasculogenic ulcers $(n=10)$

\begin{tabular}{|c|c|c|c|c|c|c|c|c|c|}
\hline \multirow[b]{2}{*}{ Domains } & \multicolumn{4}{|c|}{ First evaluation } & \multicolumn{4}{|c|}{ Second evaluation } & \multirow[b]{2}{*}{$\mathbf{P}^{*}$} \\
\hline & Average & $\begin{array}{l}\text { Standard } \\
\text { deviation }\end{array}$ & Median & $\begin{array}{l}\text { Interquartile } \\
\text { interval }\end{array}$ & Average & $\begin{array}{l}\text { Standard } \\
\text { deviation }\end{array}$ & Median & $\begin{array}{l}\text { Interquartile } \\
\text { interval }\end{array}$ & \\
\hline Health and Functioning & 15.7 & 5.9 & 16.0 & 6.6 & 26.0 & 3.0 & 27.4 & 4.0 & 0.005 \\
\hline Socioeconomic & 22.8 & 6.7 & 24.3 & 12.7 & 27.9 & 2.6 & 29.5 & 5.0 & 0.012 \\
\hline Psychological/Spiritual & 23.8 & 5.1 & 24.1 & 10.0 & 27.8 & 2.6 & 29.0 & 5.4 & 0.037 \\
\hline Family & 23.6 & 6.9 & 25.2 & 12.3 & 28.3 & 2.8 & 30.0 & 2.4 & 0.028 \\
\hline Overall score & 18.5 & 4.7 & 19.2 & 6.9 & 26.1 & 2.0 & 26.0 & 3.9 & 0.005 \\
\hline
\end{tabular}


Table 3 - Comparison of variations of quality of life scores between the characteristics of the wounds $(n=26)$ of the patients with vasculogenic ulcers

\begin{tabular}{|c|c|c|c|}
\hline $\begin{array}{l}\text { Dimensions/Characteristics of } \\
\text { the wounds }\end{array}$ & Median & $\begin{array}{l}\text { Interquartile } \\
\text { range }\end{array}$ & $\mathbf{p}$ \\
\hline \multicolumn{4}{|l|}{ Health and functioning } \\
\hline Epithelialized tissue & 24.3 & 0.0 & $0.002^{\mathrm{a}}$ \\
\hline Present foul odor & 24.3 & 0.0 & $<0.001^{\mathrm{b}}$ \\
\hline Exchange when necessary & 11.4 & 13.7 & $0.025^{\mathrm{a}}$ \\
\hline Surgical debridement & 16.5 & 10.6 & $<0.001^{\mathrm{b}}$ \\
\hline Use of hydrogel & 24.3 & 0.0 & $<0.001^{\mathrm{b}}$ \\
\hline \multicolumn{4}{|l|}{ Socioeconomic } \\
\hline Devitalized tissue & 12.8 & 10.7 & $0.001^{\mathrm{a}}$ \\
\hline Abundant exudate & 13.7 & 0.0 & $0.029^{\mathrm{a}}$ \\
\hline Serous aspect & 12.8 & 2.2 & $0.034^{\mathrm{a}}$ \\
\hline Foul odor absent & 7.3 & 10.0 & $<0.001^{\mathrm{b}}$ \\
\hline Hydrated edges & 8.8 & 10.0 & $0.023^{\mathrm{a}}$ \\
\hline Twice a week & 13.7 & 6.3 & $0.001^{\mathrm{a}}$ \\
\hline Use of alginate & 13.7 & 0.0 & $0.002^{\mathrm{b}}$ \\
\hline \multicolumn{4}{|l|}{ Psychological and spiritual } \\
\hline Epithelialized tissue & 13.7 & 0.0 & $0.003^{\mathrm{a}}$ \\
\hline Present foul odor & 13.7 & 0.0 & $<0.001^{\mathrm{b}}$ \\
\hline Hydrated edges & 5.8 & 2.2 & $0.047^{a}$ \\
\hline Surgical debridement & 6.9 & 7.7 & $0.016^{\mathrm{b}}$ \\
\hline \multicolumn{4}{|l|}{ Family } \\
\hline Devitalized tissue & 7.5 & 16.2 & $0.009^{a}$ \\
\hline Abundant exudate & 17.2 & 0.0 & $0.036^{\mathrm{a}}$ \\
\hline Absent foul odor & 7.5 & 9.5 & $0.006^{\mathrm{b}}$ \\
\hline Twice a week & 17.2 & 8.6 & $<0.001^{\mathrm{a}}$ \\
\hline Use of alginate & 17.2 & 0.0 & $0.002^{\mathrm{b}}$ \\
\hline \multicolumn{4}{|l|}{ Overall score } \\
\hline Epithelialized tissue & 15.9 & 0.0 & $0.003^{\mathrm{a}}$ \\
\hline Present foul odor & 15.9 & 0.0 & $<0.001^{\mathrm{b}}$ \\
\hline Surgical debridement & 13.8 & 5.5 & $0.003^{b}$ \\
\hline Use of hydrogel & 15.9 & 0.0 & $<0.001^{\mathrm{b}}$ \\
\hline
\end{tabular}

For the domain health and functioning, one verified characteristics that influenced the biggest increase in the quality of life scores between the first and second evaluation: epithelialized tissue $24.3( \pm 0.0)$; present foul odor $24.3( \pm 0.0)$; bandage change whenever necessary 11.4 ( \pm 13.7); surgical debridement 16.5 ( \pm 10.6$)$; and use of hydrogel $24.3(0,0)$.

In the economic field, the characteristics rela- ted to further increase in costs were: devitalized tissue $12.8( \pm 10.7)$; abundant exudate $13.7( \pm 0.0)$; serous aspect $12.8( \pm 2.2)$; absent foul odor $7.3( \pm 10.0)$; hydrated edges $8.8( \pm 10.0)$; exchange twice a week 13.7 ( \pm 6.3 ); and use of alginate $13.7( \pm 0.0)$ (Table 3).

The increase in the quality of life scores on the Psychological/Spiritual dimension was influenced by the features: epithelialized tissue $13.7( \pm 0.0)$; present foul odor 13.7 ( \pm 0.0 ); hydrated edges $5.8( \pm 2.2)$; and surgical debridement $6.9( \pm 7.7)$.

In the family domain, devitalized tissue $7.5( \pm$ 16.2); abundant exudate 17.2 ( \pm 0.0 ); absent foul odor 7.5 ( \pm 9.5); dressing changes twice a week $17.2( \pm$ 8.6); and use of alginate $17.2( \pm 0.0)$ were significant in the quality of life of patients.

In the overall evaluation, the epithelialized tissue $15.9( \pm 0.0)$; present foul odor $15.9( \pm 0.0)$; surgical debridement 13.8 ( \pm 5.5 ); and use of hydrogel $15.9( \pm 0.0)$ influenced the increase in the quality of life scores (Table 3).

There was a moderate and positive correlation between the time of existence of the wounds and the increase in the scores between evaluations in the socioeconomic domain $(\mathrm{p}=0.042, \mathrm{r}=0.402)$. One also identified high and positive correlations between the number of wounds and the increase in the quality of life scores in the field Health and Functioning $(\mathrm{p}=0.018 ; \mathrm{r}=0.725)$; and the total score $(\mathrm{p}=0.001$, $r=0.879$ ) between the first and second evaluation.

\section{Discussion}

The age variable is important in the evaluation of patients with vasculogenic ulcers, as it was observed that in this study the average age of patients was 64 years old, similar to studies conducted in the United Kingdom ${ }^{(4)}$ and in Brazil(5-6), in which participants in the first study had an average of 68.6, and the other two also average of 60 years of age. As a result, the appearance and recurrence of chronic lesions are favored by the natural physiological senescence pro$\operatorname{cess}^{(4-6)}$. 
In spite of the findings about the predominance of females ${ }^{(7)}$ a study conducted in the city of Goiânia, Brazil, showed a higher frequency of males (67.2\%) in attendance of primary care, motivated by the presence of leg ulcers, which differs from the research in question, in which there was no difference between males or females. This can be explained by the reduced number of participants, as it was also demonstrated in another study ${ }^{(8)}$.

This study aimed to analyze the socioeconomic, demographic and clinical characteristics of people with vasculogenic ulcers among population attended in bandage rooms, it indicated convergence in some socioeconomic and demographic characteristics of this population, such as low income and education (around 65.0\%) and lack of occupational activity at the time of investigation ${ }^{(6)}$, which strengthens the data seen in this study, with a predominance of participants with incomplete elementary school and retired with income, on average, of a minimum wage.

The most commonly used cover for the lesions was zinc oxide, associated with inelastic bandage without compression therapy, unlike what was done in another study that evaluated the quality of life of patients who used compression therapy by Unna boot with zinc oxide by means of the Short Form-36, and found after 12 months of therapy, the average score of 95.38, representing improvement in the quality of life of the patients analyzed according to the Short Form$36^{(9)}$.

The elastic bandage results in faster healing of venous ulcers by allowing more oxygen to flow to the wound, but in $84.6 \%$ of the injuries from the study the inelastic bandage was used due to the lack of Unna Boots in the unit ${ }^{(10-11)}$.

The antiseptic predominantly used for cleaning the perilesion was the iodopovidine but a systematic review that aimed to determine the effects of systemic antibiotics, topical antibiotics and antiseptics on the healing of venous ulcers, inferred that it is necessary further research on the effectiveness of iodopovidine and chlorhexidine in these lesions ${ }^{(12)}$.

On the analysis of the items evaluated in the Ferrans and Powers Quality of Life Index - Wounds version, the domain that had lower median score in the first evaluation was Health and Functioning 16.0 ( \pm 6.6). This result corroborates a study that aimed to verify the quality of life index of 31 patients with vasculogenic ulcers treated at a university hospital in southern Brazil, which showed the health and functioning domain with the lowest total score, but without retesting for comparison of the value during the treatment, which shows the differential of this study ${ }^{(13)}$.

For the health and functioning domain, there were features that influenced the greatest increase in the quality of life scores between the first and second evaluation, such as epithelialized tissue, present foul odor, dressing change when necessary, surgical debridement and hydrogel use. The influence of lesion characteristics on quality of life in the general health status of the areas shows progress in the aspects of quality of life from the improvement of the lesion ${ }^{(5)}$.

Similar results were observed in a study that aimed to determine the influence of care and clinical parameters on the quality of life of patients with venous ulcers, held in Rio Grande do Norte, Brazil, which showed that patients with positive characteristics in the care showed better functional capacity with less impact of pain in their quality of life $\mathrm{e}^{(5)}$.

There were significant increases in the medians of the socioeconomic domains in 5.2 units, and Psychological/Spiritual, in 4.9 units. This can be explained by the fact that, with the success of the treatment, there is less expenditure costs, such as reduction of bandage changes, causing the reduction of transportation to the clinic, among other aspects. There is also an increasing positive self-assessment related to faith, the possibility of good prognosis, and healing of lesions.

Studies have shown significant associations between psychological and social aspects and characteristics of the lesions ${ }^{(5.14)}$, this is due to the fact that negative characteristics of having vascular ulcers, such 
as strong odor, bandaged legs, difficulty in walking and others, affect the social life and self-esteem ${ }^{(5,14)}$.

The family is also important in the quality of life of individuals because it maintains the family and social structure, and it also influences the psychic structure, as a space of affection generation, care and safety ${ }^{(13)}$.

The overall score for quality of life increased by 6.8 units on average. The epithelialized tissue, the foul odor, conduction of surgical debridement and the use of hydrogel were influencing factors for the increase in the scores. In an integrative review, analysis of the studies showed that the variables pain, injury time, age and other variables of characteristics of the lesions also affected the quality of life of patients with chronic wounds ${ }^{(5,15)}$.

The results were obtained from a small sample, for this reason, it is suggested the conduction of further studies involving a larger number of participants and longer treatment time.

\section{Conclusion}

When evaluating the quality of life of patients in outpatient treatment, there was a statistically significant increase in quality of life scores, according to Ferrans and Powers Quality of life Index - Wound Version in all areas and also in the global score.

\section{Collaborations}

Monte BKS contributed to the conception, design and writing of the article. Moura ECC collaborated with the conception and design, relevant critical review of the intellectual content, article writing and final approval of the version to be published. Costa JP e Silva GRF cooperated with relevant writing and critical review of the intellectual content. Lopes VCA assisted in the analysis and interpretation of data.

\section{References}

1. Agreda JJS, Bou JET. Atenção integral nos cuidados das feridas crônicas. Petrópolis: EPUB; 2012.

2. Almeida SA, Silveira MM, Santo PFE, Pereira RC, Salomé GM. Assessment of the quality of life of patients with diabetes mellitus and foot ulcers. Rev Bras Cir Plást. 2013; 28(1):142-6.doi:http:// dx.doi.org/10.1590/S1983-51752013000100024

3. Cardozo GM, Bermudes JPS, Araújo LO, Moreira ACMG, Ulbrich EM, Balduino AFA, et al. Contribuições da enfermagem para avaliação da qualidade de vida de pessoas com úlceras de perna. Rev Estima [Internet]. 2012 [citado 2017 dez. 09]; 10(2). Disponível em: https://www.revistaestima. com.br/index.php/estima/article/view/75

4. Bland M, Dumville JC, Ashby RL, Gabe R, Stubbs N, Adderley U. et al. Validation of the VEINES-QOL quality of life instrument in venous leg ulcers: repeatability and validity study embedded in a randomised clinical trial. BMC Cardiovasc Disord. 2015; 15:85. doi: http://dx.doi.org/10.1186/ s12872-015-0080-7

5. Dias TYAF, Costa IKF, Salvetti MG, Mendes CKTT, Torres GV. Influences of health care services and clinical characteristics on the quality of life of patients with venous ulcer. Acta Paul Enferm. 2013; 26(6):529-34. doi: http://dx.doi. org/10.1590/S0103-2100201300060000

6. Malaquias SG, Bachion MM, Sant'Ana SMSC, Dallarmi CCB, Lino Junior RS, Ferreira PS. People with vascular ulcers in outpatient nursing care: a study of sociodemographic and clinical variables. Rev Esc Enferm USP. 2012; 46(2):302-10. doi:dx. doi.org/10.1590/S0080-62342012000200006

7. Malagutti WK, Kakihara CT. Curativos, estomias e dermatologia: uma abordagem multiprofissional. Martinari: São Paulo; 2014.

8. Sant'ana SMSC. Bachion MM, Santos QR, Nunes CAB, Malaquias SG, Oliveira BGRB. Úlceras venosas: caracterização clínica e tratamento em usuários atendidos em rede ambulatorial. Rev Bras Enferm. 2012; 65(4):637-44. doi: http://dx.doi. org/10.1590/S0034-71672012000400013 
9. Salomé GM, Ferreira LM. Quality of life in patients with venous ulcers treated with Unna's boot compressive therapy. Rev Bras Cir Plást. 2012; 27(3):466-71. doi: http://dx.doi.org/10.1590/ S1983-51752012000300024

10. Chamanga ET. Understanding the impact of leg ulcer bandaging on patient quality of life. $\mathrm{Br} \mathrm{J}$ Community Nurs [Internet]. 2014 [cited 2017 Dec 09]; 28(1):40-7. Available from: https:// www.researchgate.net/publication/285993818_ Understanding_the_impact_of_leg_ulcer_ bandaging_on_patient_quality_of_life

11. Flegg JA, Kasza J, Darby I, Weller CD. Healing of venous ulcers using compression therapy: Predictions of a mathematical model. J Theor Biol. 2015; 379:1-9. doi: http://dx.doi.org/10.1016/j. jtbi.2015.04.028

12. O'Meara S, Al-Kurdi D, Ologun Y, Ovington LG, Martyn-St James M, Richardson R. Antibiotics and antiseptics for venous leg ulcers. Cochrane Database Syst Rev. 2014; 1:CD003557. doi: 10.1002/14651858.CD003557.pub5
13. Sell BT, Souza MV, Martins T, Amante LN. Qualidade de vida de pessoas com úlceras vasculogênicas segundo Ferrans e Powers: versão feridas. UNOPAR Cient Cienc Biol Saúde. 2015; 17(3):1604. doi: http://dx.doi.org/10.17921/24478938.2015v17n3p\%25p

14. Dias TYAF, Costa IKF, Melo MDM, Torres SMSGSO, Maia EMC, Torres GV. Quality of life assessment of patients with and withoutvenous ulcer. Rev LatinoAm Enfermagem. 2014; 22(4):576-81. doi: http:// dx.doi.org/10.1590/0104-1169.3304.2454

15. Almeida WA, Ferreira AM, Ivo ML, Rigotti MA, Gonçalves RQ, Pereira APS. Influence of venous ulcer in patients' quality of life: an integrative review. Rev Enferm UFPE on line [Internet]. 2014 [cited 2017 Dec. 09]; 8(12):435361. Available from:https://periodicos.ufpe.br/revistas / revistaenfermagem/article/view/10512/0 